\title{
KONTRIBUSI PENGETAHUAN PARAGRAF TERHADAP KETERAMPILAN MENULIS ARGUMENTASI MAHASISWA
}

\author{
Hidayati Azkiya, Romi Isnanda \\ Universitas Bung Hatta, Indonesia \\ hidayatiazkiya@bunghatta.ac.id
}

\begin{abstract}
The purpose of this study is to know the contribution of paragraph knowledge to the skill of argument writing. Because at this time it appears that knowledge of the writing or paragraph less attention in writing. Though good writing is also seen from the writing or knowledge of paragraphs are good as well. While in the skill of argumentation writing, the student still difficulties in giving opinion or opinion of phenomenon that happened and actual moment at this time. This research method using descriptive correlational design. The population of this study are students of Indonesian Education Studies Program BP 20016/2017 which amounted to 30 people. Based on the result of research that the average knowledge of paragraph is 32,25. And the contribution of paragraph knowledge to argumentation writing skills is $12 \%$. So it can be concluded that the knowledge of paragraphs affect the skill of writing argumentation of students of Bung Hatta University School of Education, but the knowledge of the paragraph is very less that seen from the average class.
\end{abstract}

Keywords: knowledge of paragraphs; writing arguments; writing skill

\begin{abstract}
Abstrak: Tujuan penelitian ini adalah untuk mengetahui kontribusi pengetahuan paragraf terhadap keterampilan menulis argumentasi. Karena pada saat ini terlihat bahwa pengetahuan terhadap tata tulis atau paragraf kurang diperhatikan dalam menulis. Padahal tulisan yang baik itu juga dilihat dari tata tulis atau pengetahuan terhadap paragraf yang baik pula. Sedangkan pada keterampilan menulis argumentasi, mahasiswa masih kesulitan dalam memberikan opini atau pendapat fenomena yang terjadi dan teraktual pada saat sekarang ini. Metode penelitian ini menggunakan rancangan deskriptif korelasional. Populasi penelitian ini adalah mahasiswa Program Studi Pendidikan Bahasa Indonesia BP 20016/2017 yang berjumlah 30 orang. Berdasarkan hasil penelitian bahwa rata-rata pengetahuan paragraf adalah 32,25 . Serta kontribusi pengetahuan paragraf terhadap keterampilan menulis argumentasi sebesar $12 \%$. Maka dapat disimpulkan bahwa pengetahuan paragraf berpengaruh terhadap keterampilan menulis argumentasi mahasiswa Program Studi Pendidikan Bahasa Indonesia Universitas Bung Hatta, akan tetapi pengetahuan terhadap paragraf sangat kurang yang dilihat dari rata-rata kelas.
\end{abstract}

Kata Kunci: pengetahuan paragraf; menulis argumentasi, keterampilan menulis

Permalink/DOI: http:/ /dx.doi.org/10.15408/dialektika.v6i2.9045 


\section{Pendahuluan}

Tulisan yang bagus dan berkualitas tidak terlepas dari penguasaan penulisnya terhadap tata cara penulisan. Seorang penulis yang baik harus memahami EBI, kata baku, diksi, kalimat efektif, dll. Sebab pemahaman terhadap tata cara penulisan dalam paragraf dapat bermanfaat dalam menulis karangan apapun, salah satunya adalah karangan argumentasi. ${ }^{1}$ Menulis argumentasi merupakan salah satu jenis karangan dalam bahasa Indonesia untuk memaparkan dan menjelaskan permasalahan teraktual dan terpopuler dalam bidang tertentu tergantung dari penulisnya. ${ }^{2}$

Adapun teori yang digunakan adalah menurut Nurjamal dkk., bahwa menulis merupakan sebuah proses kreatif menuangkan gagasan dalam bentuk bahasa tulis untuk tujuan memberi tahu, menyakinkan, dan menghibur. ${ }^{3}$ Selanjutnya teori tentang paragraf argumentasi, Suparno dan Yunus menyatakan bahwa, paragraf argumentasi adalah ragam wacana yang dimaksudkan untuk meyakinkan pembaca mengenai kebenaran yang disampaikan oleh penulisnya. Dalam menulis paragraf argumentasi, penulis harus menyajikan secara logis, kritis, dan dan sistematis bukti-bukti yang dapat memperkuat keobjektifan dan kebenaran yang disampaikannya, sehingga dapat menghapus keraguan pembaca terhadap pendapat penulis. ${ }^{5}$

Dari uraian tersebut, dapat disimpulkan bahwa paragraf argumentasi adalah paragraf yang berisi uraian atau gagasan untuk memperdebatkan, memengaruhi, meyakinkan, mengubah sikap dan pendapat orang lain, atau membuktikan suatu kebenaran dari suatu masalah agar orang lain atau pembaca percaya dan berusaha untuk membuktikan gagasan dari suatu pemecahan masalah tersebut. Paragraf argumentasi adalah paragraf yang berisi tentang suatu pendapat, konsepsi, atau opini tertulis kepada pembaca, sehingga pembaca percaya, menerima apa yang dipaparkan oleh penulis. ${ }^{6}$ Karangan argumentasi adalah tulisan yang memuat argumen atau pendapat. Argumen tersebut menyatakan apakah seseorang tersebut sependapat atau tidak sependapat dengan

\footnotetext{
${ }^{1}$ Haryanto, "Hubungan Antara Kemampuan Menyusun Paragraf dan Motivasi Berprestasi dengan Keterampilan Menulis Laporan,” Indonesian Language Education and Literature, Vol. 1, No. 2.

${ }^{2}$ Ahmad Bahtiar dkk., Khazanah Bahasa: Memaknai Bahasa Indonesia dengan Baik dan Benar, (Bogor: In Media, 2019), h. 20-25.

${ }^{3}$ Daeng Nurjamal dkk., Terampil Berbahasa. (Bandung: Alfabeta, 2011), h. 69.

${ }^{4}$ Suparno dan Mohamad Yunus, Keterampilan Dasar Menulis, (Jakarta: Universitas Terbuka, 2008), h. $1-12$.

${ }^{5}$ Syihaabul Hudaa, Estetika Berbahasa: Mengapresiasi Bahasa Indonesia, (Sukabumi: Jejak Publisher, 2018), h. 47-53.

${ }^{6}$ Helaluddin, "Penerapan Strategi Catalisting dalam Menulis Paragraf Prosesual," Jurnal Dialektika, Vol. 3, No. 2.
} 
sebuah gagasan dengan cara mengungkapkan fakta-fakta yang ada sebagai bukti pendukung argumen sehingga orang lain akan percaya dengan argumen penulis. ${ }^{7}$

Atmazaki mengungkapkan bahwa paragraf adalah unit dasar wacana yang berisi informasi dalam suatu paket yang terorganisasi secara jelas dan memperlihatkan bagaimana potongan-potongan informasi saling terkait. ${ }^{8}$ Selanjutnya, Ramadansyah menjelaskan bahwa paragraf merupakan bagian dari karangan yang terdiri atas beberapa kalimat yang saling berhubungan secara utuh dan terpadu.' Berikutnya, Rohmadi menjelaskan bahwa paragraf adalah sekumpulan kalimat yang dirangkai atau dihubungkan sehingga membentuk suatu gagasan tertentu. Paragraf dibedakan menjadi tiga yaitu paragraf yang terbentuk berdasarkan sifat dan tujuan, berdasarkan letak kalimat utamanya, dan berdasarkan isinya. ${ }^{10}$ Dalam praktik penulisan paragraf, seorang penulis harus memahami praktik penulisan paragraf yang baik dan benar. Hal ini dikarenakan setiap siswa masih saja salah menafsirkan bentuk paragraf. ${ }^{11}$

Siahaan berpendapat bahwa paragraf adalah terdiri dari beberapa kalimat yang jumlahnya tergantung dari banyaknya menjelaskan gagasan pikiran utama. Unsur paragraf terdiri dari kalimat topik, kalimat pendukung, dan kalimat kesimpulan. $^{12}$ Dengan kata lain, suatu paragraf harus memiliki kalimat utama dan penjelas yang saling berkaitan yang membicarakan topik tertentu. ${ }^{13}$

Berdasarkan penganalisisan beberapa sumber yang memberikan batasan tentang paragraf, serta dipadukan dengan pengamatan penulis terhadap karakterinstik paragraf, dapat diambil kesimpulan paragraf adalah gabungan beberapa kalimat yang memiliki pokok pikiran dan beberapa pikiran penjelas dalam sebuah tulisan yang tersusun secara logis dan sistematis. Dalam paragraf, satu ide dijabarkan atau diuraikan dengan beberapa hal yang benar-benar

\footnotetext{
${ }^{7}$ Anri Nofitria dkk., "Pengembangan Model Pembelajaran Membaca Kritis Teks Argumentasi untuk Siswa Kelas X SMA/SMK,” Jurnal Pendidikan: Teori, Penelitian, dan Pengembangan, Vol. 2, No. 10 .

${ }^{8}$ Atmazaki, Kiat-kiat Mengarang dan Menyunting, (Padang: Citra Budaya Indonesia, 2006), h. 83.

${ }^{9}$ Ramadansyah, Paham dan Terampil Berbahasa dan Bersastra Indonesia, (Bandung: Dian Aksara Press, 2010), h. 35.

${ }^{10}$ Muhammad Rohmadi dan Aninditya Sri Nugraheni, Belajar Bahasa Indonesia: Upaya Terampil Berbicara dan Menulis Karya Ilmiah, (Surakarta: Cakrawala Media, 2011), h. 72.

${ }^{11}$ Main Sufanti, "Jenis Materi Ajar Cerita Pendek dalam Buku Siswa Bahasa Indonesia SMA dan Relevansinya dengan Kurikulum 2013,” Jurnal Bahastra, Vol. 36, No. 1.

${ }^{12}$ Leroy Holman Siahaan, "Hubungan antara Kemampuan Berpikir Logis dan Pengetahuan tentang Paragraf dengan Keterampilan Menulis Esai Bahasa Inggris,” Jurnal SOSIORELIGI, Vol. 14, No. 2.

${ }^{13}$ Syihaabul Hudaa, "Optimalisasi Bahasa: Penggunaan Bahasa yang Baik, Logis, dan Santun di Media Massa,” Jurnal Dialektika, Vol. 5, No. 1
} 
mendukung ide tersebut. Paragraf juga merupakan gabungan kalimat yang saling berhubungan secara utuh dan runut.

Pada paparan tersebut, maka jelas bahwa penguasaan terhadap paragraf sangat diperlukan dalam menulis. Karena tulisan yang baik itu juga dilihat dari tata tulisnya. Oleh sebab itu, dalam makalah ini akan dijelaskan sejauh mana kontribusi pengetahuan paragraf terhadap keterampilan menulis argumentasi mahasiswa.

\section{Metode}

Penelitian ini menggunakan rancangan argumentasi korelasional. Penelitian argumentasi diarahkan untuk menetapkan sifat dan situasi pada waktu penyelidikan dilaksanakan dengan tidak memberi perlakuan pada variabel-variabel yang terdapat pada penelitian. Penelitian argumentasi merupakan penelitian yang bermaksud untuk membuat penggambaran mengenai situasi atau kejadian-kejadian secara sistematis, faktual, dan akurat. Penelitian korelasional adalah penelitian yang berusaha mendeteksi tingkat keterkaitan variasi-variasi suatu variabel. ${ }^{14}$

Secara argumentasi, penelitian ini mendeskripsikan data dari semua variabel yang ada yakni penguasaan paragraf dan keterampilan menulis argumentasi. Secara korelasional penelitian ini berupaya mencari hubungan antara penguasaan paragraf dan keterampilan menulis argumentasi. Dari hubungan tersebut akan dianalisis lebih lanjut untuk mencari besarnya sumbangan dari tiap variabel bebas $(\mathrm{X})$ terhadap variabel terikat $(\mathrm{Y})$.

\section{Hasil dan Pembahasan}

Pada bagian ini dipaparkan dan dibahas data yang terkumpul dari hasil penelitian yang meliputi: (1) deskripsi data variabel bebas (pengetahuan paragraf) dan variabel terikat (keterampilan menulis argumentasi), (2) pengujian persyaratan analisis untuk menguji hipotesis yang meliputi uji normalitas dan uji homogenitas, (3) pengujian hipotesis, dan (4) pembahasan. Berikut ini dipaparkan hal tersebut satu persatu.

Data dalam penelitian ini terdiri atas variabel pengetahuan paragraf $(\mathrm{X})$, dan variabel keterampilan menulis argumentasi $(\mathrm{Y})$. Dari hasil pemeriksaan yang telah dilakukan terhadap data, seluruh data yang terkumpul telah memenuhi syarat untuk diolah dan dianalisis. Secara ringkas dapat diungkapkan bahwa

\footnotetext{
${ }^{14}$ Emzir, Metodologi Penelitian Kualitatif: Analisis Data, (Jakarta: Raja Grafindo, 2018), h. 27
} 
deskripsi data ini mengungkapkan informasi tentang skor total, skor tinggi, skor rendah, rata-rata, rentang, standar deviasi, modus, dan median. Selanjutnya, hasil analisis statistik deskripsi data kedua variabel dapat dilihat pada tabel 1 dan dipaparkan satu per satu sebagai berikut.

Tabel 1. Hasil Uji Statistik Deskripsi Data

\begin{tabular}{llll}
\hline No & \multicolumn{1}{c}{ Statistik } & Pengetahuan Paragraf & $\begin{array}{c}\text { Keterampilan Menulis } \\
\text { Argumentasi }\end{array}$ \\
\hline $\mathbf{1}$ & Mean & 32,25 & 62,8 \\
$\mathbf{2}$ & Median & 35,29 & 62 \\
$\mathbf{3}$ & Modus & 38,23 & 68 \\
$\mathbf{4}$ & Standar Deviasi & 12,29 & 8,92 \\
$\mathbf{5}$ & Minimum & 11,76 & 48 \\
$\mathbf{6}$ & Maksimum & 52,94 & 84 \\
\hline
\end{tabular}

Hasil pengolahan data variabel tes pengetahuan paragraf yang terdiri atas 34 butir soal yang diberikan pada 30 siswa diperoleh skor terendah 11,76 dan skor tertinggi 52,94. Hasil penghitungan dari pengetahuan paragraf data diperoleh rata-rata sebesar 32,25, median 35,29, modus 38,23 dan simpangan baku 12,29. Penghitungan tersebut menunjukkan mean, median, dan modus dari data tersebut tidak jauh berbeda. Hal ini mengidentifikasikan bahwa distribusi frekuensi variabel tes pengetahuan paragraf siswa cenderung berdistribusi normal.

Untuk memperoleh gambaran tentang pengetahuan paragraf tes pengetahuan paragraf serta grafik histogramnya akan disajikan pada tabel 2 berikut.

Tabel 2. Distribusi Frekuensi Tes Pengetahuan Paragraf

\begin{tabular}{cccc}
\hline No & Kelas interval & Frekuensi absolute & $\begin{array}{c}\text { Frekuensi relatif } \\
(\%)\end{array}$ \\
\hline $\mathbf{1}$ & $10-19$ & 7 & 23 \\
2 & $20-29$ & 3 & 10 \\
$\mathbf{3}$ & $30-39$ & 12 & 40 \\
$\mathbf{4}$ & $40-49$ & 6 & 20 \\
5 & $50-59$ & 2 & 7 \\
Jumlah & & 30 & 100 \\
\hline
\end{tabular}

Pada tabel 2, terlihat nilai frekuensi $40 \%$ dari jumlah responden memperoleh skor kelompok rata-rata pengetahuan paragraf. Sebagaimana diketahui skor rata-rata sebesar 32,25. Responden yang memperoleh skor di bawah kelas interval rata-rata adalah $33 \%$, sedangkan responden yang memperoleh skor di atas kelas interval rata-rata adalah 27\%. Secara umum, 
pengetahuan paragraf mahasiswa Prodi Pindo Universitas Bung Hatta meliputi pengetahuan terhadap kriteria paragraf yang baik, pengetahuan terhadap unsurunsur yang membangun paragraf, dan pengetahuan terhadap penggunaan bahasa secara tepat dalam sebuah paragraf. Distribusi hasil pengetahuan paragraf pada tabel 2 dapat dituangkan dalam bentuk histogram sebagai berikut.

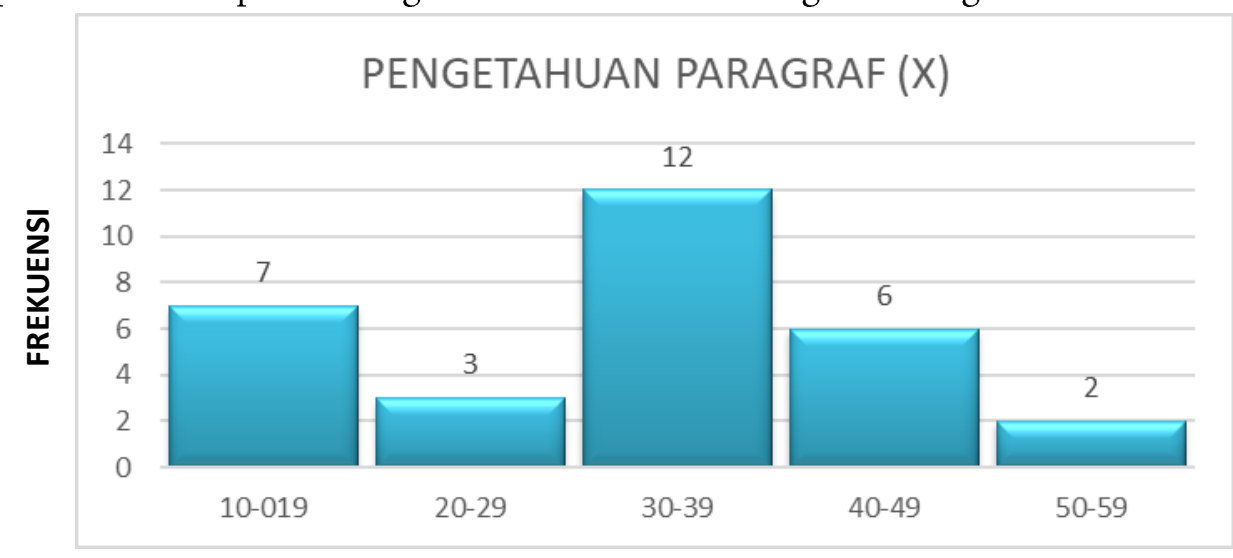

INTERVAL KELAS

Gambar 1. Histogram Distibusi Skor Pengetahuan Paragraf

Hasil pengolahan data variabel keterampilan menulis argumentasi siswa menunjukkan skor terendah 48 dan skor tertinggi 84 dari skor ideal 100. Hasil penghitungan dari pengetahuan paragraf data diperoleh rata-rata sebesar 62,8 , median 62, modus 68, dan simpangan baku 8,92. Penghitungan tersebut menunjukkan mean, median, dan modus dari data tersebut tidak jauh berbeda. Hal ini mengidentifikasikan bahwa distribusi frekuensi variabel tes keterampilan menulis argumentasi siswa cenderung berdistribusi normal.

Untuk memperoleh gambaran tentang distribusi tes keterampilan menulis argumentasi serta grafik histogramnya akan disajikan pada tabel 3 berikut.

Tabel 3. Distribusi Frekuensi Skor Keterampilan Menulis Argumentasi

\begin{tabular}{cccc}
\hline No & Kelas interval & Frekuensi absolut & $\begin{array}{c}\text { Frekuensi relatif } \\
(\%)\end{array}$ \\
\hline $\mathbf{1}$ & $40-49$ & 3 & 10 \\
2 & $50-59$ & 7 & 23 \\
3 & $60-69$ & 14 & 47 \\
4 & $70-79$ & 5 & 17 \\
5 & $80-89$ & 1 & 3 \\
Jumlah & & 30 & 100 \\
\hline
\end{tabular}


Pada tabel 3, terlihat nilai frekuensi 47\% dari jumlah responden memperoleh skor kelompok rata-rata keterampilan menulis argumentasi. Sebagaimana diketahui skor rata-rata sebesar 62,8. Responden yang memperoleh skor di bawah kelas interval rata-rata adalah 33\%, sedangkan responden yang memperoleh skor di atas kelas interval rata-rata adalah $20 \%$. Secara umum, keterampilan menulis argumentasi mahasiswa Prodi Pindo Universitas Bung Hatta meliputi ketepan penggunaan EBI, pola pengembangan paragraf, kesesuaian tema dengan isi, kelengkapan isi penjelasan, dan penggunaan diksi. Distribusi hasil keterampilan menulis argumentasi pada tabel 3 dapat dituangkan dalam bentuk histogram sebagai berikut.

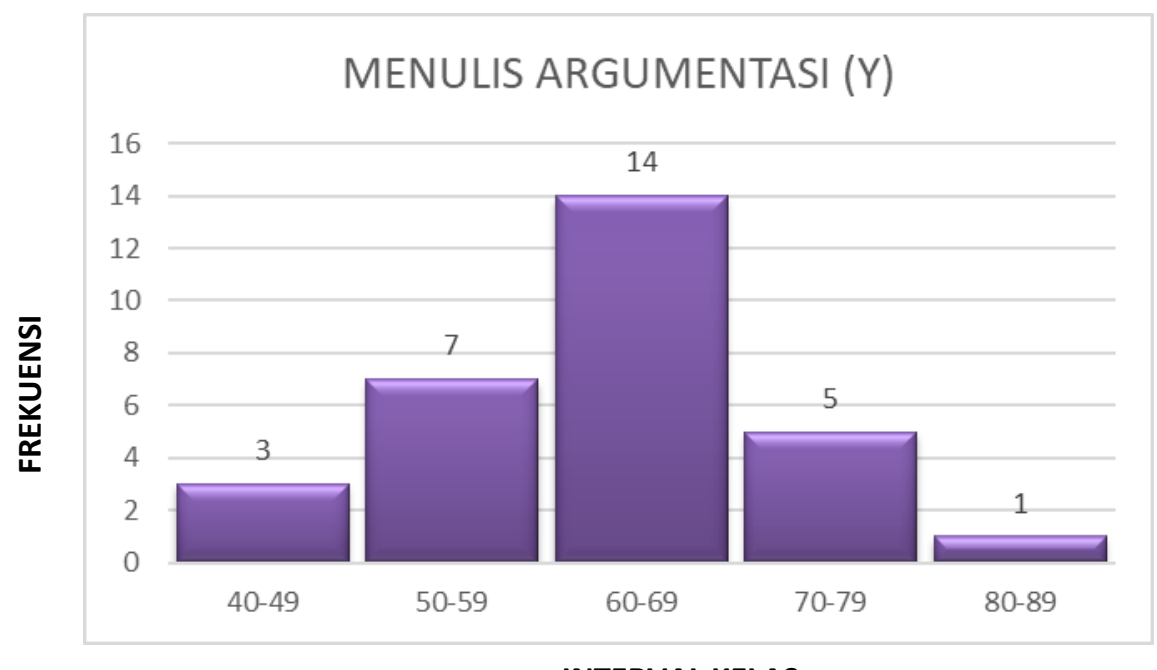

INTERVAL KELAS

Gambar 2. Histogram Distribusi Skor Keterampilan Menulis Argumentasi

\section{Pengujian Persyaratan Analisis}

Penelitian ini menggunakan rumus statistik parametris dengan menggunakan teknik analisis korelasi dan regresi. Kedua teknik ini dapat dilakukan apabila telah memenuhi beberapa persyaratan. Maka persyaratan tersebut akan diuraikan berikut ini.

\section{Uji Normalitas}

Berdasarkan penghitungan uji normalitas yang dilakukan terhadap data dari 30 responden meliputi variabel pengetahuan paragraf $(X)$, dan keterampilan menulis argumentasi $(\mathrm{Y})$ seperti terlampir dalam tabel 4 berikut. 
Tabel 4. Uji Normalitas Kedua Variabel (Lilliefors)

\begin{tabular}{clccc}
\hline No & \multicolumn{1}{c}{ Variabel } & L hitung & L tabel & Keterangan \\
1 & Pengetahuan paragraf $(\mathrm{X})$ & 0,122 & 0,125 & Normal \\
2 & Keterampilan menulis argumentasi $(\mathrm{Y})$ & 0,124 & 0,125 & Normal \\
\hline
\end{tabular}

Dengan demikian, dapat disimpulkan bahwa seluruh variabel yang meliputi pengetahuan paragraf $(\mathrm{X})$, dan keterampilan menulis argumentasi $(\mathrm{Y})$ berdistribusi secara normal.

\section{Uji Homogenitas}

Berdasarkan penghitungan uji homogenitas variabel terikat keterampilan menulis argumentasi $(\mathrm{Y})$ terhadap variabel bebas pengetahuan paragraf $(\mathrm{X})$ seperti terlampir dalam tabel 5 berikut dengan menggunakan uji Barlett.

Tabel 5. Hasil Uji Kesamaan Varians (Uji Barlett)

\begin{tabular}{lccc}
\hline Keterampilan menulis argumentasi $(\mathrm{Y})$ untuk & $\chi^{2}$ & $\chi^{2}{ }_{\text {tabel }}$ & Keterangan \\
kontribusi & 13,94 & 51,00 & Homogen \\
Pengetahuan paragraf $(\mathrm{X})$ & hitung & \\
\hline
\end{tabular}

Hasil penghitungan homogenitas keterampilan menulis argumentasi $(\mathrm{Y})$ terhadap variabel bebas pengetahuan paragraf $(\mathrm{X})$ pemasarannya ternyata homogen, sehingga Ho diterima yang artinya varians kelompok $\mathrm{Y}$ atas $\mathrm{X}$ adalah homogen.

\section{Pengujian Hipotesis}

Hipotesis yang diajukan dalam penelitian ini yaitu "Terdapat kontribusi yang signifikan pengetahuan paragraf terhadap keterampilan menulis argumentasi mahasiswa Prodi Pindo Universitas Bung Hatta”. Untuk melihat hasil penghitungan ini dilakukan pengujian hipotesis sebagai berikut.

Analisis korelasi terhadap pasangan data dari pengetahuan paragraf terhadap keterampilan menulis argumentasi menghasilkan t-hitung sebesar 37,60. Untuk lebih jelas dapat dilihat pada tabel berikut.

Tabel 6. Uji Signifikansi antara Pengetahuan Paragraf (X) terhadap Keterampilan Menulis Argumentasi $(\mathrm{Y})$

\begin{tabular}{ccc}
\hline Korelasi antara & t-tabel \\
& -hitung & $\boldsymbol{\alpha}=\mathbf{0 , 0 5}$ \\
dan Y & 37,60 & 1,67 \\
\hline
\end{tabular}


Dari tabel tersebut, dapat diungkapkan bahwa koefisien korelasi rxy $=$ sangat signifikan (t-hitung $=37,60>\mathrm{t}$-tabel $=1,67$ pada $\alpha=0,05)$. Dengan demikian, terdapat kontribusi pengetahuan paragraf terhadap keterampilan menulis argumentasi. Ini berarti semakin tinggi pengetahuan paragraf siswa, maka semakin tinggi keterampilan menulis argumentasi siswa.

\section{Pembahasan}

Koefsien korelasi sebesar 0,12 dengan arah hubungan positif (+). Artinya, semakin tinggi pengetahuan paragraf maka semakin tinggi keterampilan menulis argumentasi. Hubungan ini dapat dilihat dari nilai Asymp Sig $(0,000)<$ $\alpha(0,05)$, maka Ho ditolak. Jadi, koefisien korelasi signifikan. Artinya, ada hubungan yang signifikan antara pengetahuan paragraf terhadap keterampilan menulis argumentasi. Angka t hitung $(37,60)>$ dari t tabel $(1,67)$. Besarnya koefisien korelasi 0,12 atau hal ini berarti dari seluruh variabel independen, pengetahuan paragraf mempengaruhi keterampilan menulis argumentasi $12 \%$, sedangkan sisanya dipengaruhi oleh variabel lain.

Dari uraian tersebut, dapat disimpulkan bahwa semakin tinggi pengetahuan paragraf, maka semakin tinggi juga keterampilan menulis argumentasi. Sebaliknya, semakin rendah pengetahuan paragraf, maka semakin rendah juga keterampilan menulis argumentasi. Jadi, jelaslah bahwa terdapat hubungan positif antara pengetahuan paragraf dengan keterampilan menulis argumentasi. Temuan tersebut juga didukung dengan kenyataan di lapangan, yaitu dosen mengulang-ulang materi tentang paragraf dari segi penulisan dan pola pengembangannya, tetapi hanya pada standar kompetensi menulis.

Hal tersebut sejalan dengan pendapat Atmazaki bahwa paragraf adalah unit dasar wacana yang berisi informasi dalam suatu paket yang terorganisasi secara jelas dan memperlihatkan bagaimana potongan-potongan informasi saling terkait. ${ }^{15}$ Suparno mengemukakan bahwa deskripsi adalah ragam wacana yang melukiskan atau menggambarkan sesuatu berdasarkan kesan-kesan dari pengamatan pengalaman dan perasaan penulisnya. ${ }^{16}$ Agar terampil menulis karangan argumentasi, siswa tentu harus memiliki pengetahuan yang memadai tentang perngorganisasian dan penggunaan bahasa sebuah paragraf. Dengan pengetahuan itu, siswa berpeluang untuk terampil mengorganisasikan fakta atau peristiwa yang didapatkan di lapangan menjadi paragraf-paragraf yang padu,

\footnotetext{
${ }^{15}$ Atmazaki, Kiat-kiat Mengarang dan Menyunting... h. 87.

${ }^{16}$ Suparno dan Mohamad Yunus, Keterampilan Dasar Menulis... h. 10.
} 
runtut, dan memiliki kesatuan. Dengan demikian, menulis argumentasi yang mereka tulis tidak saja tepat, tetapi juga menarik untuk dibaca.

\section{Penutup}

Kontribusi pengetahuan paragraf terhadap keterampilan menulis argumentasi sebesar $12 \%$. Hal ini menunjukan bahwa pengetahuan paragraf secara langsung berkontribusi terhadap keterampilan menulis argumentasi mahasiswa Prodi Pindo Universitas Bung Hatta. Oleh karena itu, semakin tinggi pemahaman siswa terhadap suatu bacaan, maka akan semakin tinggi pula keterampilan menulis deskripsinya.

\section{Daftar Pustaka}

Atmazaki. Kiat-kiat Mengarang dan Menyunting. Padang: Citra Budaya Indonesia, 2006.

Bahtiar, Ahmad dkk. Khazanah Bahasa: Memaknai Bahasa Indonesia dengan Baik dan Benar. Bogor: In Media, 2019.

Emzir. Metodologi Penelitian Kualitatif: Analisis Data. Jakarta: Raja Grafindo, 2018.

Haryanto. "Hubungan Antara Kemampuan Menyusun Paragraf dan Motivasi Berprestasi dengan Keterampilan Menulis Laporan," Indonesian Language Education and Literature, Vol. 1, No. 2.

Helaluddin. "Penerapan Strategi Catalisting dalam Menulis Paragraf Prosesual," Jurnal Dialektika, Vol. 3, No. 2.

Holman Siahaan, Leroy. "Hubungan antara Kemampuan Berpikir Logis dan Pengetahuan tentang Paragraf dengan Keterampilan Menulis Esai Bahasa Inggris," Jurnal SOSIORELIGI, Vol. 14, No. 2.

Hudaa, Syihaabul. Estetika Berbahasa: Mengapresiasi Bahasa Indonesia. Sukabumi: Jejak Publisher, 2018.

Hudaa, Syihaabul. "Optimalisasi Bahasa: Penggunaan Bahasa yang Baik, Logis, dan Santun di Media Massa," Jurnal Dialektika, Vol. 5, No. 1.

Nofitria, Anri dkk. "Pengembangan Model Pembelajaran Membaca Kritis Teks Argumentasi untuk Siswa Kelas X SMA/SMK," Jurnal Pendidikan: Teori, Penelitian, dan Pengembangan, Vol. 2, No. 10.

Nurjamal, Daeng dkk. Terampil Berbahasa. Bandung: Alfabeta, 2011.

Ramadansyah. Paham dan Terampil Berbahasa dan Bersastra Indonesia. Bandung: Dian Aksara Press, 2010. 
Rohmadi, Muhammad dan Aninditya Sri Nugraheni. Belajar Bahasa Indonesia: Upaya Terampil Berbicara dan Menulis Karya Ilmiah. Surakarta: Cakrawala Media, 2011.

Sufanti, Main Sufanti. "Jenis Materi Ajar Cerita Pendek dalam Buku Siswa Bahasa Indonesia SMA dan Relevansinya dengan Kurikulum 2013," Jurnal Bahastra, Vol. 36, No. 1.

Suparno dan Mohamad Yunus. Keterampilan Dasar Menulis. Jakarta: Universitas Terbuka, 2008. 